\title{
HEADING TOWARDS INTERNET ENHANCED ESP INSTRUCTION
}

\begin{abstract}
The current study inquires into the Internet affordances and utility and focuses on its effective integration into English for Specific Purposes instruction at the Faculty of Hotel Management and Tourism. As no technological tool can of itself bring any improvements in learning, prior to its inclusion, the specific instruction context is to be investigated in order to make informed decisions in line with students' needs and interests and curricula objectives. For this reason, a survey on students' perceptions and attitudes was carried out. The findings enabled identifying the instructional aspects to be enhanced by the Internet and pointing out suggestions and remedial aspects. In general, the findings support the idea that the Internet maximum benefits can only be achieved through promoting two types of EFL language learning: overt and covert learning. Also, the overall integrative pedagogical approach is advocated.
\end{abstract}

KEYWORDS: the Internet, ESP, instruction, tourism.

1 aleksandra.radovanovic@kg.ac.rs; vladimir.kraguljac@gmail.com

This paper was submitted on July 15, 2017 and accepted for publication at the meeting of the Editorial Board held on September 19, 2017. 
Apart from having completely transformed almost all aspects of life, the Information Communication Technology (ICT) has also affected the raising of a new generation of learners. The so-called Digital Natives, whose life is inextricably linked to the Internet, social networks and various types of sophisticated electronic gadgets, understandably have posed profound challenges to their educators, Digital Immigrants, as designated by Prensky (2001). Educators have been struggling not rarely tending to employ teaching methods and techniques they themselves found most effective when they were students. Yet, facing the fact that today's students are no longer the people our educational system was designed to teach (Prensky, 2001, p. 1), educators have gradually been reshaping their teaching practices. Finally, by assimilating ICT into the teaching paradigm, Digital Natives' learning needs have been adequately answered.

In the realm of English Language Teaching (ELT), Computer-Assisted language learning (CALL) took hold. This approach, or a branch of applied linguistics, refers to "any process in which a learner uses a computer and, as a result, improves his or her language" (Beatty, 2010, p. 10). Although CALL comprises a variety of technology uses (Chapelle, 2010, p. 66), this study deals with only one of its aspects, the Internet. Due to the nature of its network contents, the Internet has turned out to be the most readily embraced technological tool immersing in English as a foreign language (EFL) classrooms on all education levels worldwide. Since the 1990s, a large body of research has been focused on the qualitative and quantitative analyses of its beneficial effects (Hubbard, 2009). The repeatedly stressed Internet affordances and advantages, in a nutshell, comprise: increasing motivation for EFL learning (Muehleisen, 1997; Warschauer, 1996), developing learner autonomy and a sense of empowerment (Warschauer \& Whittaker, 1997), being the biggest state-of-the-art information source for any field of study, a primary media of literacy and communication practices (Shetzer \& Warschauer, 2000), promoting global understanding (Lee, 2000). Also, trying to urge EFL instructors to make most of the learning opportunities of ICT, the authors have not failed to offer numerous valuable suggestions along with practical techniques 
and lessons that can be used (e.g. Đorđević, 2016; Muehleisen, 1997; Murray, 2004).

The overall purpose of the study is to inquire into the Internet affordances $^{2}$ and utility in the particular case of English for Specific Purposes (ESP), i.e. the instruction at the Faculty of Hotel Management and Tourism in Vrnjačka Banja where EL is a one-semester compulsory course in all four years of undergraduate studies. Given that the findings of the needs analysis carried out at this faculty indicated that the EFL curricula were positively evaluated (Pešić \& Radovanović, 2016), this study tends to investigate potential instructional improvement and focuses on the initial steps of the effective Internet integration.

The underlying premise is that the Internet inclusion does not necessarily yield enhanced instruction as "the computer does not in and of itself bring about improvements in learning" (Kern \& Warschauer, 2000, p. 2). The possibilities of the Internet integration are simply immense, yet, there is no proposed mode to cater to any language instructor with any students and bring about the desired outcomes. Furthermore, it is a fallacy to generalize the findings of the use of technology in ELT contexts to the field of ESP instruction (Dashestani \& Stojković, 2015). Although the viable options may be affected by the available technical equipment, the particular learning context essentially determines the utility of the Internet as the expected outcomes may differ for another setting and a different group of students.

Thus, the Internet should be carefully considered and researched under the specific conditions in order to ensure a successful integration into educational practice (Dashestani \& Stojković, 2015). Since ESP is seen as "an approach to language teaching in which all decisions as to content and method are based on the learner's reason for learning" (Hutchinson \& Waters, 1987, p. 19), students should be the first to turn to when seeking effective ways to innovate educational practices. Thus, conducting a survey to obtain the data from students was posed as the first objective as their perceptions and attitudes were taken to be of paramount importance. Only after the relevant data had been described and analysed, was it possible to identify the instructional aspects to be enhanced and make suggestions regarding learning efficiency and effectiveness

2 The term affordance refers to the potential for action or the capacity of real-world objects to help humans in executing their assertive will (Colpaert, 2006, p. 478). 
improvements, which was the second posed objective. The data interpretation enabled making informed decisions on possible enhancements in line with students' interests and attitudes and curricula objectives. Based on the insights from the relevant literature, elicited students' comments and authors' ideas, suggestions were pointed out.

To acquire the data indicating the students' attitudes and perceptions of the Internet utility, a survey questionnaire was constructed. It comprised 32 enquiry items based on a 5-point scale ranging from 'strongly disagree' to 'strongly agree's plus one open-ended question. The main issues addressed were broadly classified into three sections. Following the section containing 8 questions on attitudes and preferences for using the Internet, the second section of the questionnaire was an investigation of students' attitudes towards using the Internet for educational purposes and included 14 questions. The 9 items of the last section focused on the students' perceived benefits of using the Internet for education. Since learning will be enhanced if learners are given opportunities to contribute their own ideas, experiences and feelings (Nunan, 2012, p. 89), the last question was to elicit students' suggestions and comments.

The survey relied heavily on the Internet for designing and administering the questionnaire, as well as collecting the data. Using Google Docs, the questionnaire was designed both in Serbian and in English. With the help of the few students, the others were invited via students' Facebook groups to fill it in anonymously in the language of their choice.

\section{SURVEY FINDINGS}

Two interesting facts are worth pointing to in the beginning. Firstly, the scope of the study was limited in terms of the number of participants. The fact that 55 of about 320 students took part,

31 = strongly disagree, 2 = disagree, 3 = neutral, 4 = agree, 5 = strongly agree. 
however, may also be indicative pointing either to the general lack of motivation or insufficient or inadequate use of the networks. This could possibly prove worth investigating in some future research. Yet, the responses obtained were taken as valuable enough in drawing conclusions. Also, only two students chose to fill in the English version, whereas the vast majority optioned for the Serbian one, which may be indicative of the general attitude towards the use of English outside of class. The responses were combined, and the total average values (A), along with the questions and percentages, are presented in the tables to facilitate the interpretation of the findings.

\begin{tabular}{|c|c|c|c|c|c|c|}
\hline QUESTION & 5 & 4 & 3 & 2 & 1 & A \\
\hline Q1 I use the Internet daily. & $94.55 \%$ & $3.64 \%$ & $0.00 \%$ & $0.00 \%$ & $1.82 \%$ & 4.89 \\
\hline $\begin{array}{l}\text { Q2 I think that my computer literacy } \\
\text { is at an excellent level. }\end{array}$ & $27.27 \%$ & $54.55 \%$ & $16.36 \%$ & $1.82 \%$ & $0.00 \%$ & 4.07 \\
\hline $\begin{array}{l}\text { Q3 The Internet is a source of enter- } \\
\text { tainment, rather than a tool for } \\
\text { learning. }\end{array}$ & $5.45 \%$ & $0.00 \%$ & $40.00 \%$ & $32.73 \%$ & $21.82 \%$ & 2.35 \\
\hline $\begin{array}{l}\text { Q4 Most often, I use the Internet for } \\
\text { online chatting. }\end{array}$ & $3.64 \%$ & $29.09 \%$ & $25.45 \%$ & $30.91 \%$ & $10.91 \%$ & 2.84 \\
\hline Q5 ...* the web search. & $23.64 \%$ & $58.18 \%$ & $16.36 \%$ & $1.82 \%$ & $0.00 \%$ & 4.04 \\
\hline $\begin{array}{l}\text { Q6 ... participating in discussion fo- } \\
\text { rums. }\end{array}$ & $0.00 \%$ & $1.82 \%$ & $14.55 \%$ & $41.82 \%$ & $41.82 \%$ & 1.76 \\
\hline Q7 ...* sending e-mails. & $5.45 \%$ & $40.00 \%$ & $36.36 \%$ & $12.73 \%$ & $5.45 \%$ & 3.27 \\
\hline Q8 ...* playing online games. & $7.27 \%$ & $9.09 \%$ & $10.91 \%$ & $29.09 \%$ & $43.64 \%$ & 2.07 \\
\hline
\end{tabular}

TABLE 1: STUDENTS' ATTITUDES AND PREFERENCES FOR USING THE INTERNET

Most often, I use the Internet for...

As the findings presented in Table 1 confirmed, almost all students go online on a daily basis (94.55\%). When asked to rate their computer literacy, over the two-thirds agreed, or strongly agreed, that it was at an excellent level (Q2). The Internet was not used by students mainly for purposes related to entertainment and leisure (Q3, Q8), but rather for informative purposes and interpersonal communication.

The reported findings were in line with the results of the second section. As can be seen from the data in Table 2, the majority of 
students are aware of the Internet affordances in education. However, the findings are quite revealing in several ways. Regarding EFL learning, only a small number of respondents asserted that they did not use the Internet independently to improve their EFL knowledge (1.82\%). Interactive language learning exercises and drills available on the Internet had already been widely used by students mostly for practising grammar (Q11), as anticipated, but for practising listening techniques, as well (Q13). Although the Internet was perceived as especially valuable for boosting vocabulary (Q12, 4.18), students did not, however, express much interest in expanding specialised vocabulary through the search of hospitality and tourism (HT) terms and phrases used in authentic contexts $(\mathrm{Q} 15,3.55)$. As regards unknown words, the majority of students resorted to the use of online translation tools for words and texts $(\mathrm{Q} 16,4.31)$. However, responses to Q14 are indicative of the fact that most students did not only opt for the easiest option to grasp the meaning, as only $14.54 \%$ disagreed with the statement regarding the use of monolingual online dictionaries.

The most surprising findings are related to questions 17,18 and 19. In contrast to our expectations, but in line with responses to questions 4, 6 and 7, the data revealed that students made little use of electronic communication both in the mother tongue and in English. Emails as a medium of interaction in English were not used very frequently $(\mathrm{Q} 17,3.44)$, although insignificantly more often than emails in Serbian (Q7, 3.37). Even more rarely was the Internet used for writing texts in English and publishing them on the Internet $(\mathrm{Q} 18,1.69)$, which, in fact, proved to be the least common activity students engaged in. The even more surprising was the fact that the Internet was not widely used as a medium of oral communication (Q4, 2.84, Q19, 2.47), either.

On the other hand, students expressed slightly more positive attitudes towards the Internet use for professional purposes. Regarding the utility for academic purposes, the Internet proved to be beneficial for improving professional skills, or the knowledge of subject-matter (Q20, 3.67). Likewise, students perceived the Internet as an adequate researching tool and source of information needed for writing essays and term papers (Q10, 3.76). As for possible impediments, the students did not perceive the Internet as a time-consuming tool as they did not avoid its usage because the search took up too much time $(\mathrm{Q} 22,1.93)$, neither did they see 
significant obstacles in unsatisfactory English language knowledge in terms of reading longer texts, for instance $(\mathrm{Q} 21,2.07)$.

\begin{tabular}{|c|c|c|c|c|c|c|}
\hline QUESTION & 5 & 4 & 3 & 2 & 1 & A \\
\hline $\begin{array}{l}\text { Q9 Frequently I use the Internet in- } \\
\text { dependently to improve my EFL } \\
\text { knowledge }\end{array}$ & $30.91 \%$ & $30.91 \%$ & $36.36 \%$ & $1.82 \%$ & $0.00 \%$ & 3.91 \\
\hline $\begin{array}{l}\text { Q10 I use the Internet for reading and } \\
\text { browsing web pages in English when } \\
\text { writing essays and term papers }\end{array}$ & $29.09 \%$ & $41.82 \%$ & $16.36 \%$ & $1.82 \%$ & $10.91 \%$ & 3.76 \\
\hline Q11 ... practising grammar & $40.00 \%$ & $40.00 \%$ & $9.09 \%$ & $9.09 \%$ & $1.82 \%$ & 4.07 \\
\hline $\begin{array}{l}\text { Q12 ...* learning new words and } \\
\text { phrases }\end{array}$ & $47.27 \%$ & $30.91 \%$ & $16.36 \%$ & $3.64 \%$ & $1.82 \%$ & 4.18 \\
\hline $\begin{array}{l}\text { Q13 ...* practising listening compre- } \\
\text { hension techniques }\end{array}$ & $20.00 \%$ & $36.36 \%$ & $23.64 \%$ & $16.36 \%$ & $3.64 \%$ & 3.53 \\
\hline $\begin{array}{l}\text { Q14 ...* looking up words in online } \\
\text { monolingual dictionaries }\end{array}$ & $30.91 \%$ & $34.55 \%$ & $20.00 \%$ & $9.09 \%$ & $5.45 \%$ & 3.76 \\
\hline $\begin{array}{l}\text { Q15 ...* searching specialised vocabu- } \\
\text { lary used in authentic contexts }\end{array}$ & $21.82 \%$ & $34.55 \%$ & $27.27 \%$ & $9.09 \%$ & $7.27 \%$ & 3.55 \\
\hline Q16 I use online translation tools & $56.36 \%$ & $25.45 \%$ & $10.91 \%$ & $7.27 \%$ & $0.00 \%$ & 4.31 \\
\hline $\begin{array}{l}\text { Q17 ...* written communication in } \\
\text { English }\end{array}$ & $20.00 \%$ & $32.73 \%$ & $29.09 \%$ & $7.27 \%$ & $10.91 \%$ & 3.44 \\
\hline $\begin{array}{l}\text { Q18 I write texts in English and pub- } \\
\text { lish them on the Internet }\end{array}$ & $5.45 \%$ & $1.82 \%$ & $9.09 \%$ & $23.64 \%$ & $60.00 \%$ & 1.69 \\
\hline $\begin{array}{l}\text { Q19 ...* oral communication in Eng- } \\
\text { lish }\end{array}$ & $9.09 \%$ & $14.55 \%$ & $21.82 \%$ & $23.64 \%$ & $30.91 \%$ & 2.47 \\
\hline $\begin{array}{l}\text { Q20 ...* to improve my knowledge of } \\
\text { vocational subjects, for professional } \\
\text { development }\end{array}$ & $23.64 \%$ & $36.36 \%$ & $25.45 \%$ & $12.73 \%$ & $1.82 \%$ & 3.67 \\
\hline $\begin{array}{l}\text { Q21 I do not use the Internet for edu- } \\
\text { cational purposes because my EFL } \\
\text { knowledge is not satisfactory }\end{array}$ & $3.64 \%$ & $9.09 \%$ & $18.18 \%$ & $29.09 \%$ & $40.00 \%$ & 2.07 \\
\hline $\begin{array}{l}\text { Q22 I do not use the Internet for pro- } \\
\text { fessional development because the } \\
\text { search takes too much time }\end{array}$ & $1.82 \%$ & $12.73 \%$ & $9.09 \%$ & $29.09 \%$ & $47.27 \%$ & 1.93 \\
\hline
\end{tabular}

TABLE 2: STUDENTS' ATTITUDES TOWARDS USING THE INTERNET FOR EDUCATIONAL PURPOSES

* I use the Internet for 
Given the findings of the second section, the responses to follow could have been anticipated. As shown in Table 3, among the perceived affordances and benefits of the Internet, the following stand out: improvement of the knowledge of general EFL (Q23, 4.25) and expanding knowledge of other cultures (Q29, 4.20). By contrast, the benefits of learning ESP were significantly lower rated (3.76). Regarding four basic language skills (reading, writing, speaking, listening), the perceived merits were similarly rated in the range from 3.44 to 3.87 (Q25-Q29). In terms of motivation, however, contrary to the findings of previous studies, the students did not quite agree that the use of the Internet boosted learners' motivation $(\mathrm{Q} 30,3.60)$. Interestingly, one student even commented that the Internet, as well as other modern ICT, did not allow students to think and be more engaged in learning. Therefore, the responses to Q31 revealing that the Internet was not perceived as a must in EFL teaching (3.75) should not come as a surprise.

\begin{tabular}{|c|c|c|c|c|c|c|}
\hline QUESTION & 5 & 4 & 3 & 2 & 1 & A \\
\hline $\begin{array}{l}\text { Q } 23 \text { The use of the Internet has im- } \\
\text { proved my knowledge of general EFL }\end{array}$ & $49.09 \%$ & $34.55 \%$ & $9.09 \%$ & $7.27 \%$ & $0.00 \%$ & 4.25 \\
\hline $\begin{array}{l}\text { Q } 24 \text { The use of the Internet has im- } \\
\text { proved my knowledge of EFL for tour- } \\
\text { ism and hospitality }\end{array}$ & $30.91 \%$ & $27.27 \%$ & $30.91 \%$ & $9.09 \%$ & $1.82 \%$ & 3.76 \\
\hline $\begin{array}{l}\text { Q } 25 \text { The Internet is particularly use- } \\
\text { ful for improving reading skills }\end{array}$ & $36.36 \%$ & $32.73 \%$ & $12.73 \%$ & $12.73 \%$ & $5.45 \%$ & 3.82 \\
\hline Q 26 ... improving writing skills & $38.18 \%$ & $29.09 \%$ & $20.00 \%$ & $7.27 \%$ & $5.45 \%$ & 3.87 \\
\hline Q 27 ... improving speaking skills & $23.64 \%$ & $27.27 \%$ & $23.64 \%$ & $20.00 \%$ & $5.45 \%$ & 3.44 \\
\hline Q 28 ...* improving listening skills & $32.73 \%$ & $32.73 \%$ & $16.36 \%$ & $16.36 \%$ & $1.82 \%$ & 3.78 \\
\hline $\begin{array}{l}\text { Q 29 I have learned a lot about other } \\
\text { cultures through the Internet }\end{array}$ & $47.27 \%$ & $34.55 \%$ & $9.09 \%$ & $9.09 \%$ & $0.00 \%$ & 4.20 \\
\hline $\begin{array}{l}\text { Q } 30 \text { The use of the Internet in the } \\
\text { classroom increases learning motiva- } \\
\text { tion }\end{array}$ & $23.64 \%$ & $30.91 \%$ & $32.73 \%$ & $7.27 \%$ & $5.45 \%$ & 3.60 \\
\hline $\begin{array}{l}\text { Q } 31 \text { The Internet must be used in EFL } \\
\text { teaching }\end{array}$ & $32.73 \%$ & $27.27 \%$ & $27.27 \%$ & $7.27 \%$ & $5.45 \%$ & 3.75 \\
\hline
\end{tabular}

TABLE 3: STUDENTS' PERCEIVED BENEFITS OF USING THE INTERNET

* The Internet is particularly useful for 


\section{DISCUSSION AND SUGGESTIONS}

Widely quoted statistics that about $80 \%$ of the world's electronically stored information is in English, testifies to the fact that English has such a dominant position to be considered as the chief Internet lingua franca (Crystal, 2003, pp. 115-117). Given that ESP is based on particular educational needs of specialised learners and basically about content-based instruction, the main purpose of the Internet in ESP instruction is more than evident. As responses to Q5 indicate, students tend to make use of the abounding online information. Yet, judging from Q10 and Q20, they do not exploit the Internet content affordances as fully as possible, which is further related to Q15 responses on the engagement in searching specialised vocabulary. These findings, coupled with the fact that perceived benefits of the Internet for improving ESP were not rated very highly (Q24), clearly point to the instructional aspects to be enhanced and courses to be taken.

Firstly, there is a definite need to exploit the abundance of authentic online recourses (scholarly books and articles, newspaper and magazine articles, video materials, brochures, advertisements) more effectively. As Hubbard (2009, p. 14) states, more attention should be given to how students use computers on their own and what content and processes can help them be more successful. Promoting the use of the appropriate resources and relevant information on the subject matter, tailored to the students' needs, for both in-class instruction and after class assignments and research projects would provide students the opportunity to focus on the relevant subject and practise English.

Then again, authentic materials and specialised online corpora are ideally suited for presenting some specific language items. For instance, corpus-based analysis of discourse can come in handy to raise students' awareness of collocations. Students can be encouraged to identify the lexical items and language patterns in authentic texts and use them afterwards in their own language production. In this regard, British National Corpus (publicly available at www.natcorp.ox.ac.uk ) is quite useful. To illustrate, students can look up the most commonly used nouns (e.g. holiday, accommodation, room, tour) and find verbs, adjectives or nouns most often used with the given nouns, and use them afterwards in the sentences of their own. Also, this could be a useful way to master 
combinations of prepositions with nouns, adjectives or verbs and thus overcome the typical errors arising from the interference with the students' mother tongue (e.g. interested in not for). Various video clips, short films and educational videos on relevant topics easily accessed on video sharing website YouTube can serve a similar purpose, i.e. increasing students' productive vocabulary. To list just a few: Practising the registration in a hotel, Top 10 Hotel Management Tips for Managers in the Hospitality Industry, Worldwide careers in hotel management. In addition, materials developing intercultural competence are always a good option in this line of study. By raising awareness of cultural differences, students are getting prepared to create an effective communication with people coming from different world regions. In this regard, students' rating Q29 with a high mark (4.20) testifies of their interest in getting familiar with new cultures. Thus, task-based web activities on cultural differences created by Son $(2008$, p. 38$)$ and suggested websites set good examples of activities fostering intercultural and language knowledge and satisfying students' interests.

As for research projects, Lee (2000) points to the effectiveness of project writing, either individual or done as a pair / team work, in at least two ways: students can construct the knowledge rather than only receive it and can publish their work on the web. The third, not less valuable one, could be added: developing (re)search strategies. In fact, less than positive perceptions expressed in Q10, Q20 and Q24 could be possibly explained in terms of underdeveloped (re)search strategies. Namely, the effective use of the Internet contents requires a good level of electronic literacy, i.e. online research. Knowledge of navigating Internet sources, search for information, and critical evaluation and interpretation of what is found represents perhaps the most crucial set of electronic literacy skills (Shetzer \& Warschauer, 2000, p. 175). As memorisation is far less important than effective search strategies in this technological age (Warschauer \& Healey, 1998), ESP instructors are to assist students in acquiring these skills, even more so in the first part of the research activities. Since the Internet utility depends fundamentally on how well the materials found match the needs of the students and their ability level (Kung \& Chuo, 2002), instructors should preselect the websites best serving educational purposes and make ready to inform students on what search engines and websites to use, how to make use of search results, or even demonstrate more demanding tasks. 
Another instructional aspect to be dealt with is communication, which is of vital importance for HT professionals as a basic tool in these fields. Although the previous study indicated the insufficient level of communication skill development perceived by students (Pešić \& Radovanović, 2016), they did not, however, exploit the Internet potentials for oral or written communication in English, as indicated by Q17-Q19. Therefore, the computer-mediated communication is to be supported. The Internet used either for synchronous communication (with all users logged on and chatting at the same time) or asynchronous communication (with a delayed message system such as e-mail), as distinguished by Warschauer and Healey (1998, p. 63), will indubitably contribute to enhanced fluency. As for synchronous 'real time' oral communication, students need to be encouraged to use social networking sites, chat rooms and Skype to communicate with other learners or native speakers. This will help them push their language to greater levels of complexity (Warschauer \& Healey, 1998, p. 63). Students' responses to the last question also emphasized fostering speaking skills. As suggested by students, watching short videos such as Rick Steves' YouTube channel, the Expedia Channel featuring content on travel, destinations, attractions and useful tips from travel experts can be used as a basis for fruitful follow-up discussions. Collaborative projects regarding comparisons of several hotels, for instance, and giving spoken in-class presentations were also recommended. The fact that similar activities have been previously mentioned is best explained by the inherent capacity of the Internet based activities to combine various skills and satisfy several educational goals simultaneously.

Communication, seen also as one area of electronic literacy, involves different ways of interacting and communicating. Writing in traditional pedagogy, or construction as one area of electronic literacy (Shetzer \& Warschauer, 2000, pp. 174-5), deserves attention in this field of study, as well. More than a half of the investigated students in the previous research, $57.89 \%$, rated writing as the most needed skill for a future working place (Pešić \& Radovanović, 2016). Thus, it is equally important to provide students with greater opportunities for authentic written communication either by finding them keypals (e-mail penpals) or helping them find their own, as suggested by Muehleisen (1997) or urging them to create web pages and websites individually or collabora- 
tively. In brief, fostering EL activation both inside and outside of class should be widely promoted.

\section{PEDAGOGICAL IMPLICATIONS}

A few pedagogical implications emerge from the discussion. For one thing, by the Internet integration teacher's role attains various new shades as the teacher becomes "a guide on the site" rather than "a sage on the stage" (Warschauer \& Whittaker, 1997, p. 31). That is, from the center of the teaching process, his role shifts to the roles of facilitator, mediator, coordinator, consultant, and demonstrator. Consequently, the instructors engage in various, possibly challenging, tasks. Apart from coordinating group planning, focusing students' attention on linguistic aspects of the electronic texts, invoking awareness of genres and discourses, assisting students in developing appropriate learning strategies (Warschauer \& Whittaker, 1997, p. 31), ESP instructors contribute in other ways.

As has been pointed out, principle instructors' tasks pertaining to effective management and exploitation of online resources are closely related to the role of a material developer, and as such inherent to ESP instruction. Yet, developing materials is not such an easy task (Dashestani, 2013) and instructors should improve their own material development skills and strategies for selecting resources (Son, 2008) that could also be of use for the instructors' active role in terms of efficient (re)search guides. However, they need to possess sufficient technical and theoretical knowledge (Lee, 2000).

The appropriate pedagogical approach is another issue. Taken together, the findings and accompanying discussion imply that a well-balanced eclectic approach is preferred. In fact, effective instruction should encompass an array of varied approaches and strategies: the learner-centered and closely related learning-centered approaches underlying the ESP instruction, to begin with, then through holistic content-based, task-based, and project-based approaches, all being profoundly intertwined with communicative approach. In addition, this study argues for the affordances based approach in online pedagogy, which evaluates the potential or capacity of new technologies to enhance the language learning and teaching process (Colpaert, 2006, pp. 478- 
479). All these, being inseparable, are best seen as complementary approaches leading to the general aim to systematically educate students in the skills and knowledge they will need not only at the course of study but when the formal coursework ends as well.

Thus, the overall integrative approach is advocated. Only through the integrative Internet enhanced instruction focused on specific learning aspects in need of enhancement, can the Internet affordances be fully exploited. In this regard, the study further supports the Warschauer's (2000) third stage, or perspective, of CALL. Warschauer (2000) roughly divided the history of CALL into three main stages: structural/behavioristic, communicative and integrative CALL. Integrative CALL, characteristic of the $21^{\text {st }}$ century, features the following: multimedia and the Internet, suitability for ESP learning, language developed in social interaction, computers being principally used for authentic discourse with the principal objective being to achieve accuracy, fluency, and agency. This stage seeks to both integrate various language skills and also integrate technology more fully into the language learning process (Warschauer \& Healey, 1998, p. 58). Besides, the study also corroborates the statement that the Internet inclusion end goal should be seen through the concept of normalisation which is relevant to any kind of technological innovation and refers to the stage when the technology becomes invisible, embedded in everyday practice and hence normalised (Bax, 2003, p. 23).

Therefore, the findings of the current study support the idea that the Internet maximum merits can be achieved through promoting two types of ESP learning:

- overt learning: the Internet, as a learning tool integrated into the syllabus, being used for purposefully designed in-class activities occupying an appropriate part of every lesson and after-class assignments and projects with the primary aim to foster simultaneously mastering EFL along with the subject-matter knowledge; and

- covert learning: the Internet resources being used for various professional and non-educational purposes thus yielding improvement in overall language proficiency.

Furthermore, the merits of the proposed instruction are far-reaching. Firstly, the proposed directions could eventually lead to the changed perception of EFL as it would no longer be seen as a compulsory subject with the main goal to pass the exam (Pešić \& 
Radovanović, 2016), but rather as a meaningful means of communication and knowledge expanding. More importantly, assisting students to learn how to communicate, conduct research, and present their ideas effectively using the Internet beyond the confines of the class or semester (Shetzer \& Warschauer, 2000, p. 172) ultimately yields long-standing benefits that go far beyond ESP instruction objectives.

CONCLUSION Given the ubiquity of the Internet in the students' lives, almost in the extent of addiction, as one student commented, and the specific merits of using this state-of-the-art information source, the Internet is a useful tool enhancing ESP instruction. However, the claims presented argue against the Internet inclusion in an ad hoc and disconnected fashion. The study advocates an integrative approach including the Internet integration only if:

- the students' needs have been analysed and informed decisions regarding instruction goals made;

- the Internet based activities have been planned and developed, materials selected or adapted and all appropriately integrated into the curricula where feasible;

- integrative activities related to the subject-matter are fostered;

- attention is being paid to developing other non-language related skills; and

- instructors possess the relevant competences and are willing to engage in time-consuming and at times demanding tasks.

Despite the small-scale survey and its primarily descriptive nature, the study tended to provide insights that could contribute to improving ESP instruction.

REFERENCES Bax, S. (2003). CALL - past, present and future. System 31, 13-28.

Beatty, K. (2010). Teaching and Researching: Computer-Assisted Language Learning (2nd int. ed.). London: Pearson Education.

Chapelle, C. A. (2010). The spread of computer-assisted language learning. Language Teaching 43(1), 66-74.

Colpaert, J. (2006). Pedagogy-driven design for online language teaching and learning. CALICO Journal 23(3), 477-497.

Crystal, D. (2003). English as a global language (2nd ed.). Cambridge: Cambridge University Press. 
Dashtestani, R. (2013). EFL Teachers' Knowledge of the Use and Development of Computer-Assisted Language Learning (CALL) Materials. Teaching English with Technology 14(2), 3-27.

Dashestani, R. \& Stojković, N. (2015). The Use of Technology in English for Specific Purposes (ESP) Instruction: A Literature Review. The Journal of Teaching English for Specific and Academic Purposes, Vol.3, № 3 online 20 December 2016. Retrieved January 19, 2017 from https://www.researchgate.net/publication/282905477_The_use_of_technology_in_English_for_specific_purposes _ESP_instruction_a_literature_review

Đorđević, J. ( 2016). English language teaching methodology in a CALL classroom. Nastava i vaspitanje LXV 2/2016, 359-378.

Hubbard, P. (2009). General introduction. In: P. Hubbard (Ed.), Computer Assisted Language Learning: Critical concepts in linguistics. London: Routledge. Retrieved January 19, 2017 from https://web.stanford.edu/ efs/callcc/ callcc-intro.pdf

Hutchinson, T. \& Waters, A. (1987). English for Specific Purposes. Cambridge: Cambridge University Press.

Kern, R. \& Warschauer, M. (2000). Theory and practice of network-based language teaching. In: M. Warschauer \& R. Kern (Eds.), Network based language teaching: Concepts and practice (pp. 1-19). New York: Cambridge University Press.

Kung, S.-C., \& Chuo, T.-W. (2002). Students' perceptions of English learning through ESL/EFL Websites. TESL-EJ 6(1). Retrieved January 19, 2017 from http://www.tesl-ej.org/ej21/a2.html

Lee, K-W. (2000). English teachers' barriers to the use of computer-assisted language learning. Internet TESOL Journal 6(12). Retrieved January 12, 2017 from http://iteslj.org/Articles/Lee-CALLbarriers.html

Muehleisen, V. (1997). Projects using the Internet in college English classes. The Internet TESL Journal 3(6), 1-7. Retrieved February 1, 2017 from http:// iteslj.org/Lessons/Muehleisen-Projects.html

Murray, D. E., \& McPherson, P. (2004). Using the Web to support language learning. Sydney: National Centre for English Language Teaching and Research. Retrieved January 22, 2017 from http://www.ameprc.mq.edu.au/docs/research_reports/twnt_series/Using_the_Web.pdf

Nunan, D. (2012). Learner-Centered English Language Education. The selected works of David Nunan. New York: Routledge.

Pešić, D. \& Radovanović, A. (2016). The EL Knowledge as a Means of Enhancing Business Performance in Tourism and Hospitality - Students' Perceptions. In: 1st International Conference Tourism in Function of Development of the Republic of Serbia, Thematic Proceedings I, June 1-3 2016, Vrnjačka Banja, 
(pp. 586-602). University of Kragujevac, Faculty of Hotel Management and Tourism in Vrnjačka Banja.

Prensky, M. (2001). Digital Natives, Digital Immigrants. On the Horizon 9(5), 1-6.

Shetzer, H., \& Warschauer, M. (2000). An electronic literacy approach to network based language teaching. In: M. Warschauer \& R. Kern (Eds.), Network-based language teaching: Concepts and practice (pp. 171-185). New York: Cambridge University Press.

Son, J. B. (2008). Using web-based language learning activities in the ESL classroom. International Journal of Pedagogies and Learning 4(4), 34-43.

Warschauer, M. (1996). Motivational aspects of using computers for writing and communication. In: M. Warschauer (Ed.), Telecollaboration in foreign language learning: Proceedings of the Hawaiti symposium. (Technical Report \#12) (pp. 29-46). Honolulu, Hawai'i: University of Hawai' $i$, Second Language Teaching \& Curriculum Center. Retrieved February 10, 2017 from https://pd fs.semanticscholar.org/bb56/bd9bac7f85a36ace043c2304a9f70d6b85d.pdf

Warschauer, M. \& P. Whittaker (1997). The internet for English teaching: Guidelines for teachers. TESL Reporter 30/1, (pp. 27-33). Retrieved February 16, 2017 from https://journals.lib.byu.edu/spc/index.php/TESL/article/ viewFile/3606/3380

Warschauer, M. \& Healey, D. (1998). Computers and language learning: An overview. Language Teaching 31, (pp. 57-71).

Warschauer, M. (2000). CALL for the 21st Century. IATEFL and ESADE Conference, 2 July 2000, Barcelona, Spain. Retrieved December 29, 2016 from http://www.gse.uci.edu/markw/cyberspace.html

\author{
ALEKSANDRA M. RADOVANOVIĆ \\ VLADIMIR M. KRAGULJAC \\ УНИВЕРЗИТЕТ У КРАГУЈЕВЦУ \\ ФАКУЛТЕТ ЗА ХОТЕЛИЈЕРСТВО И ТУРИЗАМ У ВРњАЧКОЈ БАњИ
}

РЕЗИМЕ

КА УНАПРЕЪЕНОЈ НАСТАВИ ЕНГЛЕСКОГ ЈЕЗИКА СТРУКЕ ПОСРЕДСТВОМ ИНТЕРНЕТА

Овај рад се ठави интегрисањем интернета у наставу енглеског језика струке, тачније енглеског језика на Факултету за хотелијерство и туризам. Пошто ниједно технолошко средство не може само по себи довести до побољшања наставног процеса, потребно је истражити одређени наставни контекст како би се донеле одлуке у вези са ефикасном наставом, а у складу са потребама и 


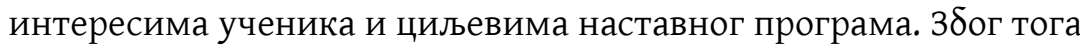
је спроведено истраживање путем анкетног упитника о перцепцијама и ставовима студената. Три скупа од 32 питања постављена у виду ставки ординалног типа (Ликертова скала) формулисана су тако да пруже увиде о општим ставовима и преференцијама испитаника у вези интернета и његовог значаја у образовне сврхе. Последње питање, питање отвореног типа, имало је за циљ да студентима пружи прилику да изнесу сопствене предлоге и коментаре.

Укратко, налази су показали да студенти употребљавају интернет у великој мери као и да су свесни свих његових преимућстава у вези образовања, укључујући и знање стручних предмета, али да га не користе у довољној мери нити на адекватан начин, како би побољшали знање енглеског језика струке. Налази истраживања омогућили су идентификовање аспеката које је потребно унапредити, као и истицање корективних мера и сугестија. Најпре, потребно је активно и ангажовано усмеравање студената на ресурсе и информације доступне путем интернета у вези учења енглеског језика, али и стручних садржаја, који им највише могу користити. Посебан нагласак је стављен на могуће начине побољшања вештина комуникације. У раду су понуђени конкретни примери активности и садржаја посебно значајни за језик дате струке.

У целини, налази подржавају став да се употребом интернета највише може постићи подстицањем две врсте учења енглеског језика: отвореног и прикривеног. У том погледу, предложен је укупни интегративни педагошки приступ, јер могућности интернета могу бити у потпуности искоришћене само кроз интегративну наставу која је усредсређена на одређене аспекте учења.

КљУчнЕ РЕчи: интернет, језик струке, настава, туризам.

Овај чланак је објављен и дистрибуира се под лиценцом Creative Commons Ауторство-Некомерцијално Међународна 4.0 (СC BY-NC 4.0 | https://creativecommons.org/licenses/by-nc/4.0/). This paper is published and distributed under the terms and conditions of the Creative Commons Attribution-NonCommercial International 4.0 licence (CC BY-NC 4.0 | https://creativecommons.org/licenses/by-nc/4.0/). 